\title{
Postencephalitic parkinsonism and basal ganglia necrosis due to Epstein-Barr virus infection
}

回再

Figure Brain MRI
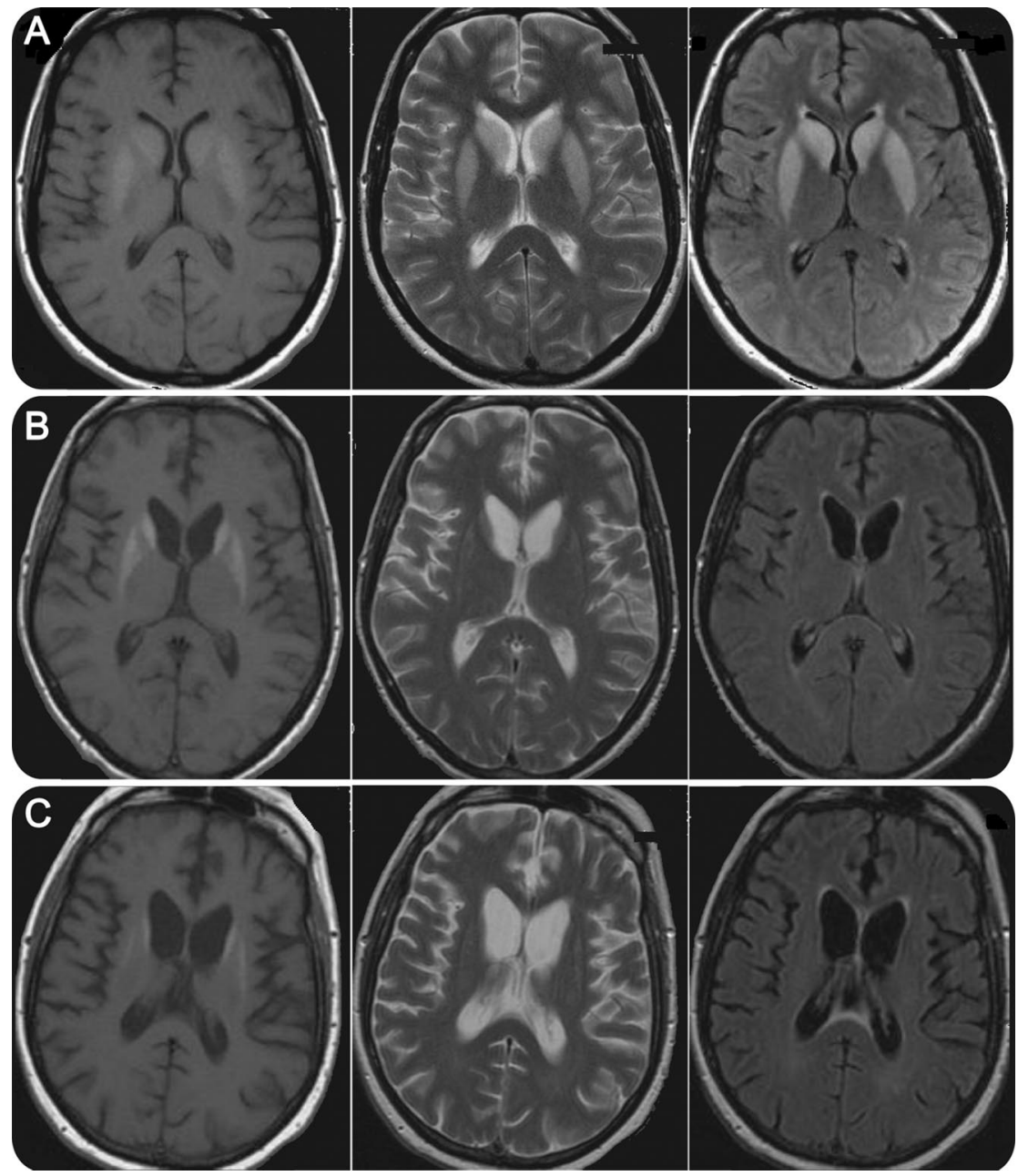

Axial brain MRI showing T1-weighted (left column), T2-weighted (middle column), and fluid-attenuated inversion recovery (right column) sequences at 1 week (A), 6 months (B), and 12 months (C) after symptom onset. Note selective hyperintensities of the caudate nuclei, putamen, and external portion of the globus pallidum bilaterally in both T1- and T2-weighted sequences, with progressive atrophy of these deep nuclei over time. Ventricular enlargement results from striatal volume loss. There was no diffusion restriction at any timepoint (not shown).

Supplemental data at www.neurology.org
A 35-year-old woman with hypertension, pancreatitis, and idiopathic renal disease developed decreased verbal output, sleepiness, and disorientation shortly after renal transplantation. MRI demonstrated striatal hyperintensity (figure, A). CSF showed 32 leukocytes (100\% lymphocytes) and normal protein $(47 \mathrm{mg} / \mathrm{dL})$ and glucose $(68$ $\mathrm{mg} / \mathrm{dL})$. Tacrolimus levels were not elevated. Epstein-Barr virus (EBV) DNA was detected by PCR $\left(1.5 \times 10^{2}\right.$ copies $/ \mathrm{mL}$ ). She evolved to a stable state of akinetic-rigid mutism with apraxia of eyelid opening (video on the Neurology ${ }^{\circledR}$ Web site at www.neurology.org). MRIs at 6 and 12 months (figure, B and C) showed progressive putaminal and caudate atrophy. Levodopa and ropinirole were ineffective. EBV causes postencephalitic parkinsonism, ${ }^{1}$ possibly due to cross-reactivity of EBV antibodies with $\alpha$-synuclein, a pathogenic Parkinson disease protein. ${ }^{2}$ 
Alberto J. Espay, MD, MSc, Cincinnati, OH; Kendrick K. Henderson, MD, Knoxville, TN

Disclosure: Dr. Espay serves on scientific advisory boards for Boehringer Ingelheim and Solvay Pharmaceuticals, Inc.; serves on the editorial advisory board for The European Neurological Journal; has received speaker honoraria from UCB/SCHWARZ PHARMA, Medtronic, Inc., and Novartis; has received honoraria from Novartis, the American Academy of Neurology, and the Movement Disorders Society; has served on speakers' bureaus for UCB/SCHWARZ PHARMA and Novartis; and receives/has received research support from Medtronic, Inc., Allergan, Inc., CleveMed, the KL2 Research Scholars mentored career development award, and NIH Institutional Clinical and Translational Science Award (RR026315-02), Dean Scholar's Award-University of Cincinnati, Davis Phinney Foundation, and the Michael J Fox Foundation. Dr. Henderson has received funding for travel from Pfizer Inc.

Address correspondence and reprint requests to Dr. Alberto J. Espay, Gardner Center for Parkinson's Disease and Movement Disorders, University of Cincinnati Academic Health Center, 260 Stetson St., Suite 2300, Cincinnati, OH 45267-0525; alberto.espay@uc.edu

1. Dimova PS, Bojinova V, Georgiev D, Milanov I. Acute reversible parkinsonism in Epstein-Barr virus-related encephalitis lethargica-like illness. Mov Disord 2006;21:564-566.

2. Woulfe J, Hoogendoorn H, Tarnopolsky M, Munoz DG. Monoclonal antibodies against Epstein-Barr virus cross-react with alpha-synuclein in human brain. Neurology 2000;55:1398-1401.

\section{NeuroImages Are Free at www.neurology.org!}

All Neurology ${ }^{\circledR}$ NeuroImages can now be freely accessed on the Neurology Web site. See them at www.neurology.org, where you can also sign up for journal email alerts and check out other online features, including the Resident \& Fellow section, the first Neurology: Clinical Practice journal, and the weekly Neurology Podcasts. 


\section{Neurology}

\section{Postencephalitic parkinsonism and basal ganglia necrosis due to Epstein-Barr virus infection}

Alberto J. Espay and Kendrick K. Henderson Neurology 2011;76;1529-1530

DOI 10.1212/WNL.0b013e318217e7dd

\section{This information is current as of April 25, 2011}

\section{Updated Information \&} Services

Supplementary Material

\section{References}

Citations

Subspecialty Collections

Permissions \& Licensing

Reprints including high resolution figures, can be found at: http://n.neurology.org/content/76/17/1529.full

Supplementary material can be found at: http://n.neurology.org/content/supp1/2011/04/24/76.17.1529.DC1

This article cites 2 articles, 1 of which you can access for free at: http://n.neurology.org/content/76/17/1529.full\#ref-list-1

This article has been cited by 1 HighWire-hosted articles: http://n.neurology.org/content/76/17/1529.full\#\#otherarticles

This article, along with others on similar topics, appears in the following collection(s):

Encephalitis

http://n.neurology.org/cgi/collection/encephalitis

MRI

http://n.neurology.org/cgi/collection/mri

Parkinson's disease/Parkinsonism

http://n.neurology.org/cgi/collection/parkinsons_disease_parkinsonism Post-infectious

http://n.neurology.org/cgi/collection/postinfectious_

Information about reproducing this article in parts (figures,tables) or in its entirety can be found online at:

http://www.neurology.org/about/about_the_journal\#permissions

Information about ordering reprints can be found online:

http://n.neurology.org/subscribers/advertise

Neurology ${ }^{\circledR}$ is the official journal of the American Academy of Neurology. Published continuously since 1951, it is now a weekly with 48 issues per year. Copyright Copyright @ 2011 by AAN Enterprises, Inc.. All rights reserved. Print ISSN: 0028-3878. Online ISSN: 1526-632X.

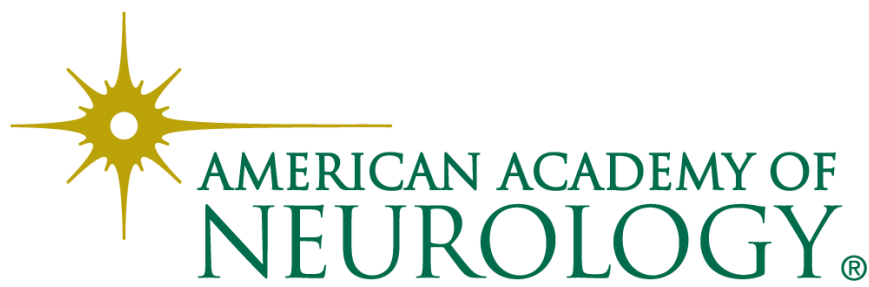

